\title{
Arborescences
}

Revue d'études françaises

\section{St. Lucian Kwéyòl on St. Croix: How gender and education affect language choice and attitudes in a multilingual context}

\section{Edward S. Mitchell et Diana Ursulin Mopsus}

Numéro 1, mars 2011

Identités linguistiques, langues identitaires : à la croisée du prescriptivisme et du patriotisme

URI : https://id.erudit.org/iderudit/1001941ar

DOI : https://doi.org/10.7202/1001941ar

Aller au sommaire du numéro

Éditeur(s)

Département d'études françaises, Université de Toronto

ISSN

1925-5357 (numérique)

Découvrir la revue

Citer cet article

Mitchell, E. S. \& Ursulin Mopsus, D. (2011). St. Lucian Kwéyòl on St. Croix: How gender and education affect language choice and attitudes in a multilingual context. Arborescences, (1), 0-0. https://doi.org/10.7202/1001941ar
Résumé de l'article

À partir d'interviews menées à l'intérieur d'une communauté de locuteurs du créole saint-lucien (kwéyòl) sur l'île Sainte-Croix (Îles Vierges des États-Unis), les auteurs ont enquêté sur l'emploi et les attitudes envers les quatre langues les plus parlées sur l'île Sainte-Croix, soit le kwéyòl, l'anglais, l'espagnol, et le créole crucien. Cet article examine les rôles de deux variables sociales, à savoir le sexe et l'éducation, quant aux questions du choix de langue et des attitudes dans cette communauté bilingue créolophone. Quelques-unes des révélations les plus remarquables de cette étude concernent les nombreuses réponses apparemment contradictoires : d'une part, une tendance générale vers la perte du kwéyòl et, d'autre part, une fierté relativement élevée à l'égard de cette langue. Les auteurs ont également observé une forte tendance indiquant un tabou contre l'usage du kwéyòl en public sur l'île Sainte-Croix, alors qu'un nombre significatif de personnes se réclamait du droit de parler le kwéyòl en public.
Tous droits réservés @ Département d'études françaises, Université de Toronto, 2011
Cecument est protégé par la loi sur le droit d'auteur. L'utilisation des services d’Érudit (y compris la reproduction) est assujettie à sa politique d'utilisation que vous pouvez consulter en ligne.

https://apropos.erudit.org/fr/usagers/politique-dutilisation/ 


\title{
S'T. LUCIAN KWEYOL ON ST. CRO
How gender and education affect language choice and attitudes in a multilingual context
}

\author{
Edward S. Mitchell and Diana Ursulin Mopsus \\ Macao Polytechnic Institute and Universidad de Puerto Rico, Río Piedras
}

\section{Introduction}

For this study, we interviewed a community of St. Lucian French-lexifier Creole (Kwéyòl) speakers on the island of St. Croix, U.S. Virgin Islands, concerning their use of and attitudes towards Kwéyòl, English, Spanish, and Crucian Creole (an English-based creole), which are the four most widelyspoken languages on St. Croix. In this article, we examine the roles of two social variables, gender and education, in shaping language choice and attitudes in this multilingual creolophone community.

St. Croix is home to the largest diaspora community of St. Lucians in the Caribbean. According to Dookhan (2006), together with Dominican nationals from the Commonwealth of Dominica, St. Lucians outnumber native Crucians on St. Croix, who make up only approximately $25 \%$ of the population. Other nationalities include Antiguans, Kittitians, Puerto Ricans, Dominicans from the Dominican Republic (not to be confused with the Commonwealth of Dominica), Palestinians, Lebanese, Chinese, and a significant Anglo-American population.

The colonial history of St. Croix is complex. Initially discovered by Spain in 1493, the island was uninhabited and abandoned by 1596 following the Spaniards' massacre of all of the resident Caribs. In the early 1600s, the Dutch and English settled the Virgin Islands almost simultaneously although, after numerous battles, the Dutch eventually abandoned the islands. The English controlled St. Croix until 1650. In that year, the Governor of St. Kitts, De Poincy, bought St. Croix as his private estate and later deeded it to the Knights of Malta. Subsequently, the French West Indian company bought the island from the Knights in 1665. Thirty years later, the French left for St. Domingue, and the island was once again abandoned. In 1733, the Danes bought St. Croix from Louis XV and opened up the island to immigration from other Caribbean islands, paving the way for the multiculturalism which characterizes St. Croix to this day. In 1754, it became a possession of the Danish crown, until it was taken over by the British from 1801-1803 and again from 1807-1815. 
The Danish returned in 1815 and in 1916 the island was sold along with St. Thomas and St. John to the U.S. for $\$ 25$ million, being named the U.S. Virgin Islands.

St. Lucians constitute a minority community and Kwéyòl is a minority language on St. Croix, competing with American English, Caribbean English, Crucian Creole, Spanish, and a number of other Caribbean creole languages. In this linguistic context, certain factors favor the maintenance of Kwéyòl among the St. Lucian community. Such factors include: strong social networks within the community, close ties to and frequent contact with family and friends on St. Lucia, and keen feelings of national pride and ethnolinguistic identity. In contrast, other powerful factors favor a shift towards English; these include the absolute dominance of English on St. Croix at the societal level, the high prestige and utility of English, and the complete absence of Kwéyòl in public media (unlike on St. Lucia, where Kwéyòl is used regularly in both broadcast and print media). Additional factors are ideological, including what Dorian (1988: 11) calls "the ideology of contempt, the belief that bilingualism is onerous, even on the individual level". Learning English does not necessitate giving up one's native tongue, yet among the participants we interviewed for this study, there was widespread belief to the contrary, eloquently expressed by one of the participants: "Patois" destroys your English!" This idea, that English proficiency is adversely affected by the use of Patois, leads many speakers to give up speaking Patois in favor of English monolingualism.

Hand in hand with the ideology of contempt, is the ideology of the superiority of standardized European languages and its antithesis, the inferiority of non-standard languages. Dorian, once again, has observed (1988: 3): “ [...] it's fairly common for a language to become so exclusively associated with low-prestige people and their socially disfavored identities that its own potential speakers prefer to distance themselves from it and adopt some other language". Both of these factors can be seen at work in the results from this study, which we now present.

In section 2, we review the methodology used to conduct the interviews, then, in section 3 , we analyze the results focusing on the variables of gender and education. Finally, in section 4, we conclude with a discussion of the results that reveal paradoxical responses from the Saint Lucian speakers concerning their attitudes towards Kwéyòl.

\footnotetext{
1 "Patois" is the Kwéyòl term used by Saint Lucian speakers to refer to their language, Saint Lucian French-lexifier Creol. Also spelled "Patwa", it comes from the French patois, meaning a non-standard, inferior dialect.
} 


\section{Methods}

Below we review the methodological design of the interviews.

\section{- Data Collection}

The method of data collection chosen for this study, the oral interview, has a number of advantages over written surveys and questionnaires. One of the first resesarchers to describe its advantages for linguistic fieldwork was Boas (1917). Without doubt, its biggest advantage is that it allows for more open-ended questions (as opposed to forced choices), which, in turn, may lead to deeper follow-up questions and revealing discussions. Often the participant becomes engaged, occasionally passionately, and loses awareness of the interview context. In short, oral interviews allow for an interactive co-construction of narrative, and can potentially be a richer source of data than written questionnaires or surveys. Additionally, the oral interview preserves a recording of speech, which, when added to a linguistic database, can be accessed by other researchers in the future for their own analyses, perhaps completely unrelated to the study for which the data were originally collected.

The semi-directed interviews, which were conducted in English and Patois, involved 29

questions (see Appendix A). The questions were adapted from a similar sociolinguistic study conducted in Guadeloupe, French West Indies (Bolus 2003).

\section{- Participants}

We interviewed a total of 26 participants. Table 1, below, provides the distribution of informants by gender and level of education, the two social categories under investigation in the study. For education, we use the terms "high school" and "high school education" to refer to the British-based equivalent levels in the St. Lucian educational system. 
Table 1: Demographics of participants

\begin{tabular}{|l|c|c|c|}
\hline & \multicolumn{2}{|c|}{ Education } & Total \\
\hline \hline & $\begin{array}{c}\text { University } \\
\text { (superior or equivalent to } \\
\text { a college degree) }\end{array}$ & $\begin{array}{c}\text { High School } \\
\text { (lower or equivalent to a high school diploma) }\end{array}$ & \\
\hline Gender & & & 15 \\
\hline Male & 6 & 9 & 11 \\
\hline Female & $\mathbf{1 4}$ & 3 & $\mathbf{2 6}$ \\
\hline Total & $\mathbf{1 2}$ & \\
\hline
\end{tabular}

All but three of the participants interviewed for this study attended school on St. Lucia, where all instruction is conducted in British English. The remaining three participants attended school on St. Croix which follows the U.S. educational system. The university group includes participants with undergraduate and graduate degrees, while the high school group includes those participants who never attended college; this latter group includes informants who completed high school as well as those who did not.

\section{- Procedure}

As a means of recruitment, we used network sampling, as developed by L. Milroy (1980), for the selection of speakers to be interviewed. Participants were asked to provide the names of other St. Lucians, which resulted in a network of contacts. Every attempt was made to obtain a representative sample of the population with respect to gender and education. For instance, when we returned to St. Croix in December 2007 to conclude the interviews, we sought out male speakers to correct an over-representation of female speakers in the sample that we had collected up to that point in time.

Prior to the interview, each participant was assigned an interview number based on the date and sequence of the interview. This information was recorded in a field notebook along with the age, gender, and education of the participant, and the time and place of the interview. Additionally, we made a note of any other persons present during the interview, as the presence of a third party can influence the interaction between the participant and researchers. All told, we made four trips to St. Croix between 2005 and 2007 to obtain the interviews.

The interviews were analyzed inductively, allowing for categories and subcategories to emerge from the data. Note that while there is a one-to-one correspondence between a category and 
a question of the interview in some cases (e.g., Table 2 Domains of use of Patois and Question 1 "Who do you talk to in Patois?"), some categories have emerged from the combined answers to more than one question (e.g., Table 3 Relatively greater positive feelings about Patois from Questions 2 and 3) and some categories have been created for which there were no corresponding questions, that is, no questions aimed at addressing specifically such a topic (e.g., Table 10 Attitudes towards Spanish).

Once the interviews had been codified according to these categories and subcategories as well as for each participant's gender, and educational attainment, we retrieved the total count and percentage for each subcategory for the total sample (“All Cases”). This process was then repeated for each subcategory, controlling for each of the independent social variables. The results have been represented in tables. We used QDA Miner (a computer program for qualitative and quantitative analysis of text-based data sets) to help manage the data and identify correlations of categories and variables.

\section{Results}

In this section, we present and analyze the results regarding three factors: domains of use of Patois, language attitudes towards Kwéyòl, and language attitudes towards other languages. The results of each category are presented in tables for "All Cases" and the two variables, gender and education. The results are presented as percentages for the two variables, and as both total count and percentages for All Cases. The results for All Cases are the number of comments made by participants that are relevant to a given category. Hence, the total count may be higher (as in Table 2) or lower (as in Table 4) than the total number of participants. This total count represents 100\% of All Cases. For each subcategory, the tables show how the number of comments is distributed (in percentages) according to the two social variables under study. In Table 2, for instance, the six participants who commented on the subcategory 1.4 Family were distributed as follows: three males $(50 \%)$ and three females (50\%); four with university education (66.7\%) and two with high school or less $(33.3 \%)$.

Due to the relatively small size of the sample (26 participants), there are cases in which the count for All Cases is quite low, hence requiring some caution when considering the distribution of the results according to the two variables. Such a small size may not be representative, especially when the percentages are very close. 


\section{- Domains of use of Patois}

The first question we asked each participant was simply, "Who do you talk to in Patois?". The results for this question are presented in Table 2 below.

Table 2 : Domains of use of Patois?

\begin{tabular}{|c|l|c|c|c|c|c|c||}
\hline $\mathbf{1 . 0}$ & & Male & Female & Univ. & HS & \multicolumn{2}{|c||}{ All Cases } \\
\hline & & $\mathbf{0}$ & $\mathbf{0}$ & $\mathbf{0}$ & $\mathbf{\%}$ & count & $\mathbf{\%}$ \\
\hline \hline $\mathbf{1 . 1}$ & $\begin{array}{l}\text { Everybody/Anybody (Kwéyòl } \\
\text { speakers) }\end{array}$ & $85.7 \%$ & $14.3 \%$ & $42.9 \%$ & $57.1 \%$ & $\mathbf{7}$ & $12.1 \%$ \\
\hline $\mathbf{1 . 2}$ & St. Lucians and Dominicans & $71.4 \%$ & $28.6 \%$ & $57.1 \%$ & $42.9 \%$ & $\mathbf{7}$ & $12.1 \%$ \\
\hline $\mathbf{1 . 3}$ & Friends & $57.1 \%$ & $42.9 \%$ & $50.0 \%$ & $50.0 \%$ & $\mathbf{1 4}$ & $24.1 \%$ \\
\hline $\mathbf{1 . 4}$ & Family & $50.0 \%$ & $50.0 \%$ & $66.7 \%$ & $33.3 \%$ & $\mathbf{6}$ & $10.3 \%$ \\
\hline $\mathbf{1 . 4 . 1}$ & Spouse & $75.0 \%$ & $25.0 \%$ & $0.0 \%$ & $100.0 \%$ & $\mathbf{4}$ & $6.9 \%$ \\
\hline $\mathbf{1 . 4 . 2}$ & Mother & $33.3 \%$ & $66.7 \%$ & $83.3 \%$ & $16.7 \%$ & $\mathbf{6}$ & $10.3 \%$ \\
\hline $\mathbf{1 . 4 . 3}$ & Father & $50.0 \%$ & $50.0 \%$ & $75.0 \%$ & $25.0 \%$ & $\mathbf{4}$ & $6.9 \%$ \\
\hline $\mathbf{1 . 4 . 4}$ & Siblings & $20.0 \%$ & $80.0 \%$ & $100.0 \%$ & $0.0 \%$ & $\mathbf{5}$ & $8.6 \%$ \\
\hline $\mathbf{1 . 5}$ & Co-workers & $0.0 \%$ & $100.0 \%$ & $33.3 \%$ & $66.7 \%$ & $\mathbf{3}$ & $5.2 \%$ \\
\hline $\mathbf{1 . 6}$ & Kwéyòl speakers who don't speak & & & & & & \\
& English & $0.0 \%$ & $100.0 \%$ & $100.0 \%$ & $0.0 \%$ & $\mathbf{2}$ & $3.4 \%$ \\
\hline Total & \multicolumn{1}{|l|}{} & & & & $\mathbf{5 8}$ & $\mathbf{9 9 . 9} \%$ \\
\hline
\end{tabular}

Of the responses provided, the most common by far was "Family", which includes particular responses mentioning family members, with a total of 25 responses, almost double that of the second most common response, "Friends". All cases revealed that most speakers use Kwéyòl when communicating with family members, which suggests that Kwéyòl is spoken primarily in the home and in private settings.

The variables gender and education revealed variation. Beginning with gender, the disproportionate number of male participants who responded that they spoke Patois to "Anybody/Everybody" may be related to them having larger social networks than the female participants we interviewed. The men may come into contact with a wider variety of Caribbean Creole speakers for this reason. The significant differences in reporting talking Kwéyòl to family members observed between those with a university education and those without is noteworthy. It appears that the more highly-educated participants use Kwéyòl exclusively in the home with "Family", "Mother", "Father", and "Siblings", whereas those with less education may speak Kwéyòl in other domains, such as the work place. 


\section{- Language attitudes towards Kwéyòl}

The next set of categories examines language attitudes. While the main focus of the questions was attitudes towards Kwéyòl, participants often commented how they felt about Spanish and Crucian, two other widely-spoken languages on St. Croix. Language attitudes, as noted by Fasold (1984), extend beyond language and also target their speakers. Thus, participants' attitudes towards Crucian and Spanish can be interpreted as a reflection of their attitudes towards speakers of these languages.

As for Kwéyòl, we see that while attitudes towards this language are overwhelmingly positive, at the same time, there is a taboo against speaking Kwéyòl in public that emerges in the interviews. This apparent contradiction is evidence of the persistence of negative attitudes towards Kwéyòl among its speakers, many of whom to this day refer to the language as "broken", "crude", and "illegitimate". This apparent contradiction can no doubt be partially explained by what L.-F. Prudent (1980) terms créolophobie, characterized by a hatred of Creole, similar to Frantz Fanon's description of Afro-Caribbean auto-odi (Fanon 1952). According to Ninyoles (1969: 97):

This term corresponds to the fact that the individual implicated in such a linguistic conflict denies the existence [of Creole]. What's more, he attempts to move towards the dominant language and the cultural and social behavioral models that it transmits. It also corresponds to an abandonment of one's own values and of one's original language and social identity. (translation by Edward S. Mitchell)

The first category to be considered is 2.0 , the results for which are presented in Table 3 below.

Table 3: Relatively greater positive feelings about Patois

\begin{tabular}{|l|l|c|c|c|c|c|c||}
\hline $\mathbf{2 . 0}$ & & Male & Female & Univ. & HS & \multicolumn{2}{|c|}{ All Cases } \\
\hline & & $\mathbf{0}$ & $\mathbf{0}$ & $\mathbf{\%}$ & $\mathbf{\%}$ & count & $\mathbf{\%}$ \\
\hline $\mathbf{2 . 0}$ & $\begin{array}{l}\text { Mere mention of } \\
\text { the category }\end{array}$ & $100.0 \%$ & $0.0 \%$ & $0.0 \%$ & $100.0 \%$ & 1 & $3.8 \%$ \\
\hline $\mathbf{2 . 1}$ & $\begin{array}{l}\text { Beautiful, the best, } \\
\text { proud }\end{array}$ & $61.5 \%$ & $38.5 \%$ & $53.8 \%$ & $46.2 \%$ & 13 & $50.0 \%$ \\
\hline $\mathbf{2 . 2}$ & $\begin{array}{l}\text { Different, unique, } \\
\text { special }\end{array}$ & $0.0 \%$ & $100.0 \%$ & $100.0 \%$ & $0.0 \%$ & 3 & $11.5 \%$ \\
\hline $\mathbf{2 . 3}$ & Beneficial & $55.6 \%$ & $44.4 \%$ & $66.7 \%$ & $33.3 \%$ & 9 & $34.6 \%$ \\
\hline Total & & & & & & $\mathbf{2 6}$ & $\mathbf{9 9 . 9} \%$ \\
\hline
\end{tabular}

Looking at 'All Cases' in Table 3, we can observe that 50\% reported considering Patois to be beautiful, "the best", or were proud of the language, while another third considered Patois to be beneficial. As for gender, those reporting Patois to be "different, unique, or special" were exclusively 
female, otherwise there is little variation by gender on this question. Turning to education, we can see that $100 \%$ of those who consider Kwéyòl to be "different, unique, special" have a university education, as was the case for those who consider Kwéyòl to be beneficial.

As shown in Table 4 below, category 3.0 contains three subcategories: relatively less positive (good) feelings, indifferent, and the feeling that Patois is a broken/crude language.

\section{Table 4: Relatively less positive feelings about Patois}

\begin{tabular}{|l|l|c|c|c|c|c|c||}
\hline $\mathbf{3 . 0}$ & & Male & Female & Univ. & HS & \multicolumn{2}{|c|}{ All Cases } \\
\hline & & $\mathbf{0}$ & $\mathbf{\%}$ & $\mathbf{\%}$ & $\mathbf{\%}$ & count & $\%$ \\
\hline $3 \mathbf{3}$ & $\begin{array}{l}\text { Relatively less positive } \\
\text { (good) }\end{array}$ & $33.3 \%$ & $66.7 \%$ & $50.0 \%$ & $50.0 \%$ & 6 & $54.5 \%$ \\
\hline $\mathbf{3 . 2}$ & Indifferent & $100.0 \%$ & $0.0 \%$ & $50.0 \%$ & $50.0 \%$ & 2 & $18.1 \%$ \\
\hline $\mathbf{3 . 3}$ & Patois is broken/crude & $100.0 \%$ & $0.0 \%$ & $100.0 \%$ & $0.0 \%$ & 3 & $27.2 \%$ \\
\hline Total & & & & & & $\mathbf{1 1}$ & $\mathbf{9 9 . 8} \%$ \\
\hline
\end{tabular}

As shown by 'All Cases' in Table 4, the most negative qualification makes up just over a quarter of the total responses for this category with most negative attitudes expressed by male participants. As for education, we see clearly that the most negative attitudes towards Kwéyòl were expressed by participants with a university education.

In summary, those expressing a negative attitude towards Kwéyòl constitute a small minority: the overwhelming majority of participants expressed great pride in the language. Those with a university education distinguish themselves as the group exhibiting the greatest degree of conflict: on the one hand, they are the most likely to condemn Kwéyòl as broken or crude, while on the other, they extol the benefits of being able to speak the language. Most likely, the more educated speakers use very little Kwéyòl outside of family settings due to the fact that they consider this language too colloquial ("broken/crude") for such settings.

The next measure of language attitudes is based on participants' responses to the question, “Do you consider Patois to be a language?" (Category 4.0), analyzed in Table 5 below. 
Table 5: Consideration of Patois as a language

\begin{tabular}{|l|l|c|c|c|c|c|c||}
\hline \hline 4.0 & & Male & Female & Univ. & HS & \multicolumn{2}{|c|}{ All Cases } \\
\hline & & $\mathbf{0}$ & $\mathbf{0}$ & $\mathbf{0}$ & $\mathbf{\%}$ & Count & $\mathbf{\%}$ \\
\hline $\mathbf{4 . 1}$ & Definitely yes & $68.4 \%$ & $31.6 \%$ & $52.6 \%$ & $47.4 \%$ & 19 & $65.5 \%$ \\
\hline \multirow{2}{*}{$\mathbf{4 . 1 . 1}$} & $\begin{array}{l}\text { Yes, but not } \\
\text { standardized }\end{array}$ & $0.0 \%$ & $100.0 \%$ & $100.0 \%$ & $0.0 \%$ & 2 & $6.9 \%$ \\
\hline $\mathbf{4 . 1 . 2}$ & Yes, but not recognized & $66.7 \%$ & $33.3 \%$ & $100.0 \%$ & $0.0 \%$ & 3 & $10.3 \%$ \\
\hline $\mathbf{4 . 1 . 3}$ & Yes, but "broken" & $33.3 \%$ & $66.7 \%$ & $66.7 \%$ & $33.3 \%$ & 3 & $10.3 \%$ \\
\hline $\mathbf{4 . 2}$ & No & $50.0 \%$ & $50.0 \%$ & $50.0 \%$ & $50.0 \%$ & 2 & $6.9 \%$ \\
\hline Total & & & & & $\mathbf{2 9}$ & $\mathbf{9 9 . 9} \%$ \\
\hline
\end{tabular}

The data clearly indicate that the majority (19 of 29) of participants definitely considered Kwéyòl to be a language, while just over a quarter of participants responded, "Yes, but ...". 2 Those responding "No" (two individuals) were a minority. The breakdown by gender reveals that those who responded, "Yes, but ..." were female, whereas those who responded, “definitely, yes" were male. Turning to education, we can observe the "Yes, but ..." responses to be almost exclusively limited to the group which had received a university education. Those with a high school education or less were much more confidently categorical.

The results for the next category to be discussed under language attitudes (Category 16.0) are summarized in Table 6 below.

Table 6: Language most comfortable speaking now

\begin{tabular}{||l|l|c|c|c|c|c|c||}
\hline $\mathbf{1 6 . 0}$ & $\begin{array}{l}\text { Language most } \\
\text { comfortable speaking } \\
\text { now }\end{array}$ & Male & Female & Univ. & HS & \multicolumn{2}{||}{ All Cases } \\
\hline & & $\%$ & $\%$ & $\%$ & $\%$ & count & $\%$ \\
\hline \hline $\mathbf{1 6 . 1}$ & English & $42.9 \%$ & $57.1 \%$ & $85.7 \%$ & $14.3 \%$ & 7 & $26.9 \%$ \\
\hline $\mathbf{1 6 . 2}$ & Patois & $85.7 \%$ & $14.3 \%$ & $0.0 \%$ & $100.0 \%$ & 7 & $26.9 \%$ \\
\hline $\mathbf{1 6 . 3}$ & Both & $50.0 \%$ & $50.0 \%$ & $50.0 \%$ & $50.0 \%$ & 6 & $23.1 \%$ \\
\hline $\mathbf{1 6 . 4}$ & Depends on situation & $66.7 \%$ & $33.3 \%$ & $66.7 \%$ & $33.3 \%$ & 6 & $23.1 \%$ \\
\hline Total & & & & & & 26 & $\mathbf{1 0 0 . 0} \%$ \\
\hline
\end{tabular}

2 In Table 5, the expression "yes, but..." demonstrates an ambiguous and contradictory attitude towards Patois since the majority of participants responding "yes" felt the need to qualify their affirmation of Kwéyòl being a language. 
The data from 'All Cases' are almost equally distributed among the four subcategories "English", "Patois", "Both", and "Depends on situation". 86\% of those who responded "Patois" were male, whereas $57 \%$ of those responding "English" were female. Those responding "Depends on situation" were also twice as likely to be male as female. This rather striking contrast is not, however, especially surprising, since we have seen that women are more inclined to consider English to be the language with which they are the most comfortable. This could be an indicator of a current shift in the use of language, a shift that favors English on St. Croix. With respect to education, the data reveal that $86 \%$ of participants who responded that the language they were most comfortable speaking is English had a university degree, while 100\% of those who responded "Patois" had a high school diploma or less.

For Category 23.0, the results represent parents' perception of their children's attitudes (Table 7).

Table 7: Children's feelings about Patois as perceived by participant

\begin{tabular}{|l|l|c|c|c|c|c|c||}
\hline \hline 23.0 & & Male & Female & Univ. & HS & \multicolumn{2}{|c|}{ All Cases } \\
\hline & & $\mathbf{0}$ & $\mathbf{\%}$ & $\mathbf{0}$ & $\mathbf{\%}$ & count & $\mathbf{\%}$ \\
\hline $\mathbf{2 3 . 1}$ & Positive & $100.0 \%$ & $0.0 \%$ & $0.0 \%$ & $100.0 \%$ & 1 & $4.0 \%$ \\
\hline $\mathbf{2 3 . 1 . 1}$ & Like it/love it & $60.0 \%$ & $40.0 \%$ & $20.0 \%$ & $80.0 \%$ & 5 & $20.0 \%$ \\
\hline $\mathbf{2 3 . 1 . 2}$ & Want to learn it & $42.9 \%$ & $57.1 \%$ & $71.4 \%$ & $28.6 \%$ & 7 & $28.0 \%$ \\
\hline $\mathbf{2 3 . 2}$ & Indifferent & $66.7 \%$ & $33.3 \%$ & $33.3 \%$ & $66.7 \%$ & 3 & $12.0 \%$ \\
\hline $\mathbf{2 3 . 3}$ & $\begin{array}{l}\text { Regret not being able to } \\
\text { speak it }\end{array}$ & $25.0 \%$ & $75.0 \%$ & $100.0 \%$ & $0.0 \%$ & 4 & $16.0 \%$ \\
\hline $\mathbf{2 3 . 4}$ & Prefer English & $100.0 \%$ & $0.0 \%$ & $75.0 \%$ & $25.0 \%$ & 4 & $16.0 \%$ \\
\hline $\mathbf{2 3 . 5}$ & Don't know & $100.0 \%$ & $0.0 \%$ & $0.0 \%$ & $100.0 \%$ & 1 & $4.0 \%$ \\
\hline Total & & & & & $\mathbf{2 5}$ & $\mathbf{1 0 0 . 0} \%$ \\
\hline
\end{tabular}

Overall, $28 \%$ of the participants wanted their children to learn Patois, while $20 \%$ of them thought that their children liked the language. Even if $16 \%$ of the parents regret that their children were not able to speak it, the same proportion of interviewees reported that their children preferred to speak English. While the parents expressed the wish that their children learn Patois, they believed that learning English is more important.

Regarding gender, fathers reported that their children preferred to speak English, but that they wanted to learn Kwéyòl and like it, while $57 \%$ of those who reported that their children wanted to learn Patois and $75 \%$ of those who regretted the fact that they were not able to speak it were 
female. It appears that both genders reported that their children wanted to learn Patois, but fathers, maybe for professional reasons, insisted that their children preferred English.

Turning to the variable education in Table $7,71.4 \%$ of parents who had a university degree thought that their children wanted to learn Patois and 100\% reported that their children expressed regret for not being able to speak it. However, $75 \%$ of parents with a university education reported that their children preferred to speak English. In the case of parents with a high school diploma or less, 80\% thought that their children liked Patois. This feeling may have resulted from the experience of the parents as children. It is possible that parents with a university education had been prohibited from speaking Patois when they were younger and, as a result, did not speak the language themselves. A result of this prohibition may have been that they did not teach Patois to their children and regret it now. In the case of parents with a high school diploma, they already knew how to speak Patois, spoke it to their children, and had a positive attitude about their children's feelings.

Category 30.0 was one of the categories to emerge from the data. We did not have a question on the use of Kwéyòl in public to start with, but upon transcribing the interviews, we discovered that there were sixteen comments referring to the use of Kwéyòl in public, which led us to create Category 30.0, the results for which are presented in Table 8 below.

Table 8: Speaking Kwéyòl in public

\begin{tabular}{||l|l|c|c|c|c|c|c||}
\hline \hline $\mathbf{3 0 . 0}$ & & Male & Female & Univ. & HS & \multicolumn{2}{|c||}{ All Cases } \\
\hline & & $\mathbf{0}$ & $\mathbf{\%}$ & $\mathbf{\%}$ & $\mathbf{\%}$ & count & $\mathbf{\%}$ \\
\hline \hline $\mathbf{3 0 . 1}$ & Caution against & $100.0 \%$ & $0.0 \%$ & $50.0 \%$ & $50.0 \%$ & 2 & $12.5 \%$ \\
\hline $\mathbf{3 0 . 2}$ & Negative perception of & $75.0 \%$ & $25.0 \%$ & $75.0 \%$ & $25.0 \%$ & 8 & $50.0 \%$ \\
\hline $\mathbf{3 0 . 3}$ & The right to do so & $16.7 \%$ & $83.3 \%$ & $33.3 \%$ & $66.7 \%$ & 6 & $37.5 \%$ \\
\hline Total & & & & & $\mathbf{1 6}$ & $\mathbf{1 0 0 . 0} \%$ \\
\hline
\end{tabular}

In 'All Cases', 50\% of the participants had a negative perception of speaking Kwéyòl in public. However, $37.5 \%$ of the participants claimed the right to speak the language in public. Of those who reported a negative perception of speaking Kwéyòl in public, 75\% were male in contrast to $83.3 \%$ of females who claimed the right to do so. These results mirror those of Category 23.0 (Table 7), in which fathers reported that their children preferred to speak English while mothers emphasized that their children liked Kwéyòl and wanted to learn it. Here, then, these results reveal participants' insecurity about Kwéyòl while, at the same time, demonstrating evidence of covert prestige. Recall that we observed in Category 2.0 (Table 3) that the majority of those with a positive attitude towards 
Patois, defined as "beautiful, the best, proud", were male; yet here we see that the same social group, males, cautioned against speaking Kwéyòl in public and manifested a negative perception of speaking the language in public.

The prestige of Patois seems to depend on the situational context, public versus private. One possible explanation of the gender differences that we have observed is that St. Lucian men may work in construction with workers from other countries speaking different languages and so may have to adapt to the linguistic situation, whereas St. Lucian women may have arrived on St. Croix after their husbands already had jobs. The latter may be more likely to stay at home or, if they do work outside the home, they may still have Kwéyòl input working with St. Lucian or Dominican coworkers.

With respect to educational attainment, three-quarters of St. Lucian participants who had a negative perception of speaking Kwéyòl in public had a university degree whereas two-thirds of participants who claimed the right to do so had a high school diploma at best. Thus, there is a correlation between the attitude towards speaking Kwéyòl in public in terms of both gender and educational attainment. The more educated participants would have had much greater exposure to English and to educated non-Kwéyòl speakers, and therefore be more keenly aware of the prestige of English and the ideology of contempt and stigma attached to speaking Kwéyòl.

\section{- Attitudes towards other languages.}

As mentioned previously, St. Croix is a multilingual island where other languages, such as English, Spanish, and Crucian Creole are used on a daily basis. This section provides an analysis of the attitudes of Saint-Lucian speakers towards two other languages widely spoken on St. Croix, namely Crucian Creole and Spanish.

For Category 25.0, in general, St. Lucian participants living on St. Croix had a lukewarm/mitigated opinion about Crucian as shown in Table 9 below. 
Table 9: Attitudes towards Crucian language

\begin{tabular}{|l|l|c|c|c|c|c|c||}
\hline \hline 25.0 & & Male & Female & Univ. & HS & \multicolumn{2}{|c|}{ All Cases } \\
\hline & & $\mathbf{0}$ & $\mathbf{\%}$ & $\mathbf{\%}$ & $\mathbf{\%}$ & count & $\mathbf{\%}$ \\
\hline $\mathbf{2 5 . 1}$ & $\begin{array}{l}\text { Negative/disparaging } \\
\text { (incorrect, improper) }\end{array}$ & $20.0 \%$ & $80.0 \%$ & $80.0 \%$ & $20.0 \%$ & 5 & $55.6 \%$ \\
\hline $\mathbf{2 5 . 2}$ & $\begin{array}{l}\text { Positive - attempt to } \\
\text { use it }\end{array}$ & $0.0 \%$ & $100.0 \%$ & $100.0 \%$ & $0.0 \%$ & 4 & $44.4 \%$ \\
\hline Total & & & & & & $\mathbf{9}$ & $\mathbf{1 0 0 . 0} \%$ \\
\hline
\end{tabular}

Even if over half of respondents considered the Crucian language as negative and disparaging, a good percentage of the sample attempted to use it and receive it positively. Only one male provided his opinion, which was negative. In contrast, females had a mitigated opinion: some reported positive attitudes, while an equal number manifested a negative and disparaging attitude.

Being a French-lexifier creole, St. Lucian Kwéyòl does not compete with English, and therefore is not seen as one of its varieties. In contrast, Crucian Creole is perceived as being in competition with English, as it is an English-lexifier creole considered by many to be bad or broken English. Given that St. Lucian Kwéyòl is autonomous, it is more likely than Crucian Creole to be considered a language by St. Lucians and other English speakers.

Category 27.0 was another category to emerge from the data after inductive analysis. The results are summarized in Table 10 below.

Table 10 : Attitudes towards Spanish

\begin{tabular}{|c|c|c|c|c|c|c|c|}
\hline \multirow[t]{2}{*}{27.0} & & \multirow{2}{*}{$\begin{array}{c}\text { Male } \\
\%\end{array}$} & \multirow{2}{*}{$\begin{array}{c}\text { Female } \\
\%\end{array}$} & \multirow{2}{*}{$\begin{array}{c}\text { Univ. } \\
\%\end{array}$} & \multirow{2}{*}{$\begin{array}{c}\text { HS } \\
\%\end{array}$} & \multicolumn{2}{|c|}{ All Cases } \\
\hline & & & & & & count & $\%$ \\
\hline 27.0 & $\begin{array}{l}\text { Mere mention of } \\
\text { category }\end{array}$ & $100.0 \%$ & $0.0 \%$ & $50.0 \%$ & $50.0 \%$ & 2 & $16.7 \%$ \\
\hline 27.1 & Utilitarian & $100.0 \%$ & $0.0 \%$ & $100.0 \%$ & $0.0 \%$ & 2 & $16.7 \%$ \\
\hline 27.1.1 & $\begin{array}{l}\text { Participant speaks some } \\
\text { Spanish }\end{array}$ & $100.0 \%$ & $0.0 \%$ & $33.3 \%$ & $66.7 \%$ & 3 & $25.0 \%$ \\
\hline 27.2 & $\begin{array}{l}\text { As a prestigious world } \\
\text { language }\end{array}$ & $33.3 \%$ & $66.7 \%$ & $66.7 \%$ & $33.3 \%$ & 3 & $25.0 \%$ \\
\hline 27.3 & $\begin{array}{l}\text { Participant regrets not } \\
\text { speaking/ } \\
\text { understanding it - } \\
\text { wants to learn }\end{array}$ & $0.0 \%$ & $100.0 \%$ & $50.0 \%$ & $50.0 \%$ & 2 & $16.7 \%$ \\
\hline Total & & & & & & 12 & $100.1 \%$ \\
\hline
\end{tabular}


Based on 'All Cases', the participants had a positive attitude towards Spanish. Twenty-five percent said that they speak some Spanish and an equal number consider it a prestigious world language. These attitudes may well be influenced by the presence of a significant Puerto Rican population on St. Croix, especially those from the island of Vieques who arrived around 1927 in order to labor in the sugar cane plantations in the Virgin Islands. This period coincided with the arrival of the U.S. Navy in Vieques, which uprooted and displaced hundreds of Puerto Rican families, many of whom were resettled on St. Croix.

$100 \%$ of St. Lucian participants who considered Spanish to be a language used for utilitarian purposes had a university degree, as did two-thirds of those considering it a prestigious world language. Curiously, these educated participants were much less likely to actually speak Spanish than their less educated compatriots.

Two-thirds of St. Lucian participants who reported speaking some Spanish had a high school diploma or less. By way of explanation, it may be more of a necessity of survival in a communicational context, for example at school and at work. In the case of school, most children whose parents have a high school diploma are placed in public school and are exposed to a multilingual context: English, Spanish, Crucian, and various other Caribbean creoles. The language that they speak at home is often different from the language used at school. In order to integrate into the school and to communicate with their classmates, they learn to speak English. In the case of the children whose parents have a university degree, the majority are placed in private schools, where fewer Caribbean dialects of English are spoken and where the representation of Standard English as the language of educational and professional achievement is well spread. In the educational system on St. Croix, there are children from St. Croix, Puerto Rico, the Dominican Republic, St. Lucia, Dominica, and other islands; there is a mosaic of languages used at school. It seems that, as was the case with Category 23.0 "Children's feelings towards Patois" (table 7), St. Lucian participants with a university degree were more theoretical than practical. Indeed, St. Lucian participants who had a higher education wanted their children to learn Patois and thought that Spanish is utilitarian. This does not mean that they spoke it or valued it at the university. However, St. Lucian participants who had a high school diploma at best liked Patois, meaning that they enjoyed speaking it and may have also spoken some Spanish for communicational needs in the multicultural society that exists on St. Croix. 


\section{Conclusion}

The results from our study have shown how gender and education play a role in questions of language choice and attitudes among this diaspora community of Kwéyòl-speakers on the multilingual island of St. Croix, U.S. Virgin Islands. We have seen that the vast majority of participants consider Kwéyòl to be a language. A breakdown of the data by variables revealed that those who responded "Yes, but ..." were female and those with a university education. The responses of the male participants and those participants with less education were more categorical, whereas female and more educated participants were more likely to insist on attaching contingencies.

Data from the variables of gender and education revealed that those most comfortable speaking Patois were male and those with no university education. Those responding that they felt most comfortable speaking English had a university education. This is evidence of a strong correlation between higher education and the loss of Kwéyòl. That male participants are more comfortable speaking Patois most likely arises from the fact that they reported using it much more in social networks outside of the family than female participants.

Some of the more remarkable revelations of this study were found in the many apparently conflicting responses. On the one hand, we observed a general trend towards the loss of Kwéyòl, yet on the other, pride in the language is exceedingly high. We observed a strong tendency pointing towards a taboo against speaking Kwéyòl in public on St. Croix, while at the same time, a significant number proclaimed the right to speak Kwéyòl in public.

In Category 16.0 ("Language most comfortable speaking now"), the variables of gender and education revealed that those most comfortable speaking Patois were male and participants with no university education. Those responding that they felt most comfortable speaking English had a university education. Turning to attitudes towards other languages spoken on St. Croix, participants' opinions about the Crucian language were sharply polarized. However, all participants responding to Category 27.0 ("Attitudes towards Spanish") had a positive attitude. All participants who considered Spanish to be a language used for utilitarian purposes had a university degree, while two-thirds of those considering it a prestigious world language had only primary or secondary education.

The future implications of these findings remain to be seen. In terms of language maintenance and shift, given the fact that fewer St. Lucian children on St. Croix are learning Kwéyòl despite great pride in the language, we would predict that future generations of St. Lucians on St. Croix will be monolingual English speakers, perhaps with command of a few token Kwéyòl 
expressions. One motivation for this prediction is what Dorian (1988) labels "prestige transfer", whereby the prestige associated with a specific language is transferred to the speaker of that language. This is the case of English on St. Croix (and on St. Lucia and throughout the Anglophone Caribbean) and essentially the reverse of the creole dynamic, whereby the stigmatization attached to the language is transferred to the speaker. These processes are often inseparable and simultaneous, yet far from inevitable.

The multilingualism on St. Croix is not an isolated case, especially in the Caribbean. However, the dominant ideology tends to promote the idea of the superiority of monolingualism. In multilingual communities such as those found on St. Croix, this ideology joins the forces of globalization, urbanization, and cultural assimilation to encourage, if not to oblige, the rejection of minority languages towards a monolingual submission to the language of global domination, English.

\section{References}

Boas, Franz. 1917. Introductory. International Journal of American Linguistics 1: 1-8.

Bolus, Mirna. 2003. Enquête sociolinguistique menée auprès de collégiens de langues et cultures régionales créoles en Guadeloupe. Retrieved 22 August 2005 from http://www.potomitan.info/ linivesite/sociolinguistique.html.

Dookhan, Isaac. 2006. A bistory of the Virgin Islands of the United States. Kingston, Jamaica: Canoe Press.

Dorian, Nancy. 1988. Western language ideologies and small-language prospects. In Endangered languages: Language loss and community response, ed. Lenore Grenoble and Lindsay Whaley, 3-21. Cambridge: Cambridge University Press.

Fanon, Franz. 1952. Peau noire, masques blancs. Paris: Seuil.

Fasold, Ralph. 1984. The sociolinguistics of society. Oxford: Blackwell.

Milroy, Lesley. 1980. Language and social networks. Oxford: Blackwell.

Ninyoles, Rafael Lluis. 1969. Conflicte lingüístic valencià. Barcelona: Edicions 62.

Prudent, Lambert-Félix. 1980. Des baragouins à la langue antillaise: analyse bistorique et sociolinguistique du discours sur le créole. Paris: Éditions Caribéennes. 


\section{Appendix}

Interview questions

1. Who do you talk to in Patois?

2. How do you feel about Patois?

3. Do you consider Patois to be a language?

4. Which language do you use most everyday?

5. Which languages did your parents speak when you were a child?

6. Which languages do they speak now?

7. Were you ever forbidden from speaking Patois?

8. Where? When?

9. Were you ever punished for speaking Patois?

10. What was the first language you spoke as a child?

11. Which language did you use to talk to your parents?

12. Which language do you feel most comfortable speaking now?

13. Which language do you use when talking to friends?

14. Can you read St. Lucian Patois?

15. Which languages do you speak to your children?

16. When do you use one or the other?

17. Which language do your children speak to you?

18. Which language do your children use to talk with their friends?

19. How do your children feel about Patois?

20. What is the status of Patois in St. Lucia today?

21. What do you think about government efforts to promote it?

22. Do you think that Patois has a place in the schools in St. Lucia?

23. Tell me about the English Patois

24. Do you speak it?

25. Who speaks it?

26. Have you ever been discriminated against in St. Croix for being St. Lucian?

27. Do you have any questions for me? 